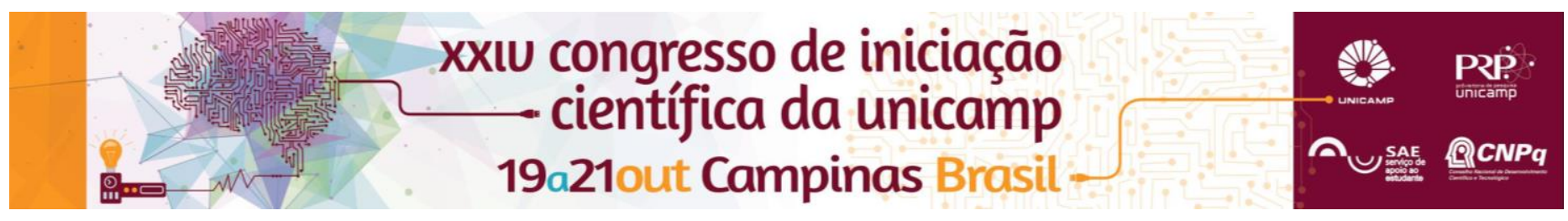

\title{
A construção de um "escândalo": barebacking, mídia e produção de sentidos
}

\author{
Autor: Jadir Marques de Souza*
}

\begin{abstract}
Resumo
Esta pesquisa visa reconstituir um recente escândalo na mídia brasileira a respeito do clube do carimbo, supostamente uma rede de homens que defendem e praticam o sexo sem preservativo. $O$ escândalo remete à discussão sobre a prática do barebacking, tematizada por parte da literatura científica sobre HIV/Aids e definida aqui como sexo sem preservativo intencional e, em geral, entre homens. $O$ eixo de análise são as disputas de sentido em torno de categorias que constituem a polêmica. Para isso, toma-se como objeto de estudo as reportagens sobre o clube do carimbo publicadas em diferentes veículos no período de janeiro a julho de 2015 , e propõe-se uma reflexão sobre as categorias e informações geradas pela polêmica.
\end{abstract}

\section{Palavras-chave:}

Sexualidade; mídia; moralidades.

\section{Introdução}

Esta pesquisa objetiva mapear e analisar a construção de uma polêmica na mídia brasileira a respeito do clube do carimbo, supostamente uma rede de homens que defendem e praticam o sexo sem preservativo. Situando os atores sociais, discursos e posições envolvidas, viso salientar os contenciosos, negociações e deslocamentos envolvidos na construção do clube do carimbo enquanto um escândalo ligado à produção de pânicos morais. O intuito não é produzir uma relativização sobre a suposta prática sexual, mas mapear a produção desse escândalo no deslocamento de categorias e seus efeitos.

\section{Resultados e Discussão}

A metodologia utilizada foi a etnográfica com documentos, lançando mão da compilação, observação e análise de documentos online, principalmente reportagens, relacionados ao clube do carimbo e publicados em diferentes veículos entre janeiro a julho de 2015, período no qual o "escândalo" foi gestado e atingiu seu ápice, com publicações nos mais acessados portais de notícia do país, discussões entre ativistas e a proposição de um projeto de lei que torna crime hediondo transmitir o HIV, consciente e deliberadamente, à outra pessoa (PL 198/2015).

É relevante dizer que, tal como Lowenkron (2015) fez em relação à violência sexual contra crianças, não me debruço sobre a existência ou não do clube do carimbo, mas o recoloco em uma "economia dos discursos" sobre práticas, riscos, prazeres e perigos, seguindo e analisando a rede que produz a forma pela qual esse tema passou a ser discutido e entendido como um problema.

Dois pontos particularmente significativos dessa rede e que, aparentemente, auxiliaram na repercussão e sedimentação do escândalo sobre o clube do carimbo, foram notícias veiculadas pelo site Terra (I) e pelo jornal O Estado de São Paulo (II). Diz-se em (I) que os sujeitos integrantes do suposto clube do carimbo procurariam por "jovens gays" na internet para, após um encontro e o uso de diversas técnicas de persuasão, realizar sexo sem preservativo. Já em (II) narra-se sobre "homens barebackers" que desejariam transmitir o HIV e que formariam um clube do carimbo, entendido como uma festa, na qual soropositivos estariam dispostos a transmitir o HIV propositalmente ou com consentimento. Ou seja, enquanto em (I), o clube do carimbo é caracterizado como um grupo restrito, formado por homens que visavam persuadir "jovens gays" a realizar sexo sem preservativo e se comunicavam através da internet, em (II), o clube do carimbo se assemelha a uma festa na qual a transmissão do HIV é, por vezes, desejada pelos participantes. A articulação desses dois sentidos enseja a constituição de um "escândalo", entendido por Lowenkron (2008) como a vinculação da denúncia pública, caracterizada pela formalização e publicização de caráter acusatório, e a fofoca, a qual é mais fluída e polimorfa, circulando em rede de boca a boca. Esse fenômeno assume propriedades sociológicas particulares, uma vez que provoca a proliferação de discursos morais sobre temas que são socialmente considerados tabus.

\section{Conclusões}

A pesquisa permitiu demonstrar que a produção do clube do carimbo está imersa em um complexo jogo de posições e estratégias envolvendo moralidades e acusações, e articula diversos discursos, práticas e sistemas classificatórios, muitas vezes díspares, os quais são organizados e recebem inteligibilidade e coerência através da formação de um escândalo. Assim, o escândalo não é um dado a priori, mas um efeito que gera sentido.

Destarte, conclui-se que o clube do carimbo é um mote para o escândalo e para as pessoas formularem acusações morais e tecerem significados sobre o sexo sem preservativo.

\section{Agradecimentos}

Agradeço ao $\mathrm{PIBIC/CNPq}$ pelo financiamento dessa pesquisa. À Isadora Lins França, pela atenciosa orientação. À Laura Lowenkron, à Carolina Branco de C. Ferreira e à Regina Facchini pelos generosos comentários ao longo da realização desta pesquisa.

LOWENKRON, L. O Monstro Contemporâneo: a construção social da pedofilia em múltiplos planos. Rio de Janeiro: EdUERJ, 2015.

. Sexualidade e (Menor)idade: estratégias de controle social em diferentes escalas. (Dissertação de Mestrado), UFRJ, Rio de Janeiro, 2008. 